\title{
Interests and Identity in European Monetary Integration: France and Britain
}

\section{CH $O$ H ong Sik}

(Beijing Foreign Studies University)

\section{$\langle$ CONTENTS〉}

I. Introduction

II. Interests or Identity: Theoretical evaluation

1. Interest-based explanations

2. Identity-based explanations

3. Bridging the gap

III. Hypotheses for the synthesis

1. Core-Periphery

2. Issue Specificity

3. Agent
IV. Commitment, Resentment, and Calculation

1. Between Head and Heart

2. Common Elusiveness

3. Pride and Instrument

4. Indifferent masses?

V. Conclusion

- Keyword: Europe, monetary integration, interests, identity, France, Britain

\section{【ABSTRACT】}

The aim of this article is to explain the different French and British attitudes toward European monetary integration. The starting point is the critical evaluation of existent approaches in providing a satisfactory explanation of Franco-British differences. Both interest- and identity-based approaches provide a partially relevant explanation but fail to capture other important dimensions. Our attempt is then to formulate an articulated synthesis combining these two approaches and to propose some operational hypothesis. Positing two opposite models of action, one rationalist and the other constructivist, and assuming a continuum between these two extremes, we elaborate the basic analytic framework. Then, we propose four operational hypotheses on European integration concerning the core-periphery dimension, the distributional consequences of the issue, the rapport of the issue to the national formation and identity, and the agent involvement dimension. Analyzed in the light of these four dimensions, the explanation becomes more 
complete and satisfactory. In France, the globally pro-European identity shared by the masses combined with the economic elites support or neutrality was opportunistically and successfully exploited by political elites. On the contrary, in Britain, the political and economic elites were both hesitant on the monetary integration, as well as on the European integration in general, constantly measuring the pros and cons of participation. The masses attitude against monetary integration reflects the particular status of the national currency in their historical imaginary and the peripheral nature of British European commitment. Our synthetic framework seems to produce a more comprehensive account and explanation than each approach considered in isolation.

\section{I . Introduction}

Why are France and Britain so different in their relationship to Europe? France has been a leading country for major steps of European integration, while Britain proved to be consistently reluctant. From the beginning of European integration in the 1950's to the present monetary integration, France has often been the inspiring pro-European leader. Britain, on the contrary, has maintained a skeptical vision and a hesitant approach to Europe. These contrasting attitudes and policy stance are all the more remarkable that both countries have comparable size of population and level of economic development, and share the same liberal democratic political system ${ }^{1)}$.

In recent decades, the European monetary integration projects and processes have crystallized this contrasting pattern of French enthusiasm and British reluctance. The Franco-German couple initiated every important step towards monetary integration from the Werner report of 1970 to European Monetary System (EMS) and Economic and Monetary Union (EMU). Britain has persistently maintained an arms-length relationship to these different projects and systems. Therefore, explaining and understanding the Franco-British difference on monetary integration can be a first step to the comprehension of their more general differences in various dimensions of European integration. Furthermore, the monetary integration is all the more important that it involves not only political and economic elites but also populace. In other words,

1) Helen Wallace states that "British experience of European integration has been persistently quite different from that of France, the obvious comparator country": Helen Wallace, "At Odds with Europe", Political Studies, XLV, (1997). 
this policy question becomes also an eminently political issue with its emotional and symbolic dimension.

The rich literature on European integration proposes diverse approaches which may explain this empirical puzzle. For our purpose, two different accounts of national interest or state preference formation can be distinguished. On the one hand, the interest-based approaches insist mainly on the 'objective' economic conditions of the state to explain its preference ${ }^{2}$. The identity-based approach, on the other hand, underlies the role of ideas, beliefs, and identity to explain member-states engagement in the process of European integration". It is nevertheless surprising to see each approach claiming its' own superiority in explanation without serious attempts to combine their different perspective. The debate has been organized around an alternative questioning of the causes of state preference in the either form. Moravcsik, for example, compares systematically the relative role of geopolitical/ideological and economic/commercial factors in state preference formation to conclude in favor of prevalence of the latter factors ${ }^{4)}$. Constructivists insist upon the preeminence of identity factors in explaining the same outcome ${ }^{5}$. Our point of departure is an effort to overcome this dichotomous vision of causal factors and to introduce a rather dialectical perspective.

Our purpose in this article is to elaborate a synthetic analytical framework in order to explain the process of state preference formation with regard to European monetary

2) Barry Eichengreen and Jeffrey Frieden(eds.), The Political Economy of European Monetary Unification, (Boulder: Westview Press, 1994); Barry Eichengreen, "Dental Hygene and Nuclear War: How International Relations Looks from Economics", International Organization 52, 4, (1998); Andrew Moravcsik, "Preferences and Power in the European Community: A Liberal Intergovernmentalist Approach”, Journal of Common Market Studies, Vol.31, No.4, (1993); Andrew Moravcsik, "Taking Preferences Seriously: A Liberal Theory of International Politics", International Organization, Vol.52, No.4, (1997); Andrew Moravcsik, The Choice for Europe: Social Purpose and State Power from Messina to Maastricht, (Ithaca: Cornell University Press, 1998); Henning, C. Randall, "Systemic Conflict and Regional Monetary Integration: The Case of Europe", International Organization, 52, 3, (1998).

3) Kathleen McNamara, The Currency of Ideas: Monetary Politics in the European Union, (Ithaca: Cornell University Press, 1998); Thomas Risse, with Daniela Engelmann-Martin, Hans-Joachim Knopf and Klaus Roscher, "To Euro or Not to Euro? The EMU and Identity Politics in the European Union”, European Journal of International Relations, Vol.5, No.2, (1998); M. Marcussen, T. Risse, D.Engelmann-Martin, H-J. Knopf, and K.Roscher, "Constructing Europe? The Evolution of French, British and German Nation State Identities", Journal of European Public Policy, Vol.6, No.4, (1999); Michael Merlingen, "Identity, Politics and Germany's Post-TEU Policy on EMU”, Journal of Common Market Studies, Vol.39, No.3, (September, 2001).

4) Moravsik(1998).

5) Risse et al.(1998). 
integration. First, it is necessary to bridge the gap between interest- and identitybased approaches. One of the major shortcomings of existent approaches was to suppose that the same model of explanation could be valid for every context, regardless of time, space, culture, or actor. The originality of this article resides not in underlining the complementary character of the contending approaches but in elaborating a synthetic theoretical framework combining both in a common body of hypothesis. Second, the synthesis has to be conceptually rigorous and comparatively applicable. Contextsensitive constructivist explanations have been too often conceptually fragile and too rigidly context-specific. Third, populace has to be introduced and taken seriously in the process of state preference formation. Even though the role of elites has been the most visible in European integration, the interests and identities of masses were sometimes crucial in explaining state preferences. Fourth, we are conscious of the active role of institutional factors, but we don't explicitly take them into account in our framework in order to maintain concision and comprehensiveness in the first place. The influence of the institutional factors should be fully considered in a more empirically oriented research.

The article is organized as follows. It begins by critically evaluating the contending approaches to European monetary unification. Then, it considers the possibility of building a synthetic approach of the European integration in general and of the monetary integration process in particular, focusing on the role played by the masses. Finally, the article explores the empirical fitness of this approach with regard to two contrasting cases, France and Britain.

\section{II . Interests or Identity: Theoretical evaluation}

What makes Britain so different from France in European monetary integration? Various contending theories deal with the explanation of the European integration in general, and of the monetary integration in particular. Since monetary policy forms one of the two most important macroeconomic policies for a state, the economic theories and the subsequent interest-based explanations of political science have been dominant until recently. Identity-based explanations, however, have brought about a new perspective in the last decade. In this section, interest- and identity-based approaches will be successively examined. 


\section{Interest-based explanations}

The first interest-based theoretical perspective comes directly from economics. The optimal currency area (OCA) theory states that a country benefits from a currency union if it shares the same business cycle with the other countries forming the union ${ }^{6}$. In this approach, France along with Germany, Benelux and Austria form a core group of European countries sharing a common business cycle. Britain does not make a "strong" economic case for participation. Nevertheless, this interest-based theory at the national level doesn't seem to provide a clear-cut answer as to whether one country should or should not participate to the monetary cooperation or union. As Artis puts it ${ }^{7}$, even though "the UK is a marginal candidate for EMU", "economic analysis imposes no imperatives; the decision is a political one". This economic explanation is congruent with empirical facts. Britain, out of sync in her economic cycle with core continental countries, remained outside the EMU. France was one of the favorite candidates for EMU participation and is in fact inside the Euro-zone. But other countries from Southern or Northern Europe such as Greece, Ireland or Finland made a choice nonconsistent with economic theories prediction.

Political economists refined this cost-benefit model formulated at the national macroeconomic level by introducing interest group dimension. The main argument of the interest group models focuses on the changing economic incentives of individuals and firms at the microeconomic level. The development of intra-regional trade and investment increases the extent and the power of individuals engaged in the production and consumption of tradable goods and capital, thus making the exchange rate stability at the European level more attractive. On the contrary, those in non-tradable sectors lose the most from the loss of national monetary autonomy following monetary integration. These distributional preferences of domestic interest groups combined with linkage politics explain the state preference ${ }^{8)}$.

The liberal intergovernmentalism also provides a political economic theory of state preference formation based on the liberal vision of state-society relations. The economic

6) Robert Mundell, "A Theory of Optimum Currency Areas", American Economic Review, 51, (1961); Ronald McKinnon, "Optimum Currency Areas", American Economic Review, 53, (1963).

7) Michael J. Artis, The UK and the EMU, EU Working Papers RSC No.67, (Florence: European University Institute, 2000), pp.14-6.

8) Jeffrey A. Frieden, "The Impact of Goods and Capital Market Integration on European Monetary Politics", Comparative Political Studies 29, (1996); Jeffrey A. Frieden, "Invested interests: The Politics of national economic policies in a world of global finance", International Organization 45, No.4, Autumn (1991); Jeffrey A. Frieden, "The euro: Who wins? Who loses?, Foreign Policy, September (1998). 
interests, and especially the producers' interests, are the main determinants of national preference: "In monetary policy, preferences for integration reflected the relative macroeconomic performance and preference of national governments alongside commercial consideration" ${ }^{9)}$. In this theoretical perspective, the Franco-British difference on European monetary integration reflects the objective economic conditions as well as the political elites' preference on the course of economic policy.

These interest-based approaches have certain commonalities. First, the macro- and micro-economic explanations, as well as the political economic theory, posit a materialistic model of analysis. The material interests are given priority in the determination of actors' preferences and decision making. While economic theory doesn't provide a direct and definite answer to the state preference, the liberal intergovernmentalism as well as the interest group model put forward the preeminence of economic and commercial interests in national preference formation by comparison with geopolitical and ideological considerations. These views however tends to ignore or reduce the identity dimension to ideas, ideological orientation, or geopolitical factors. This way of considering the ideational factors denies the constitutive role of identity or culture in the determination and definition of national interests or state preference. Second, the interest-based approaches are rationalistic. Actors are presumed to be active utility-maximizing calculators oriented by means-end spirit. The logic of consequence is the driving force to explain the actors' preferences and action. This characteristic imposes a short term bias in considering the time horizon of actors. The immediate consequences of a decision are often favored at the expense of long term perspective. Third, this model supposes the same political process for every context. The same model of interest intermediation or aggregation is supposed to be at work in all states.

\section{Identity-based explanations}

In the 1950's and 1960's the neo-functionalist theories in their variant versions recognized the role of ideas and identity in the European integration process. Political integration itself was defined in terms of transfer of political loyalty, by political and economic elites, from the national level to the supranational one ${ }^{10)}$. This political integration

9) Moravcsik(1998), p.6.

10) "Political integration is the process whereby political actors in several distinct national settings are persuaded to shift their loyalties, expectations and political activities toward a new center, whose institutions possess or demand jurisdiction over the pre-existing national 
was to be the functional reflection of the on-going economic integration, each type of integration supporting the other by the process of 'spill over'. These first attempts to theorize regional integration were then criticized for their quasi-automatic nature and over-optimistic supranationalism to be 'falsified' by historic evolution. They were abandoned and replaced by more 'national static' approaches of intergovernmentalism. However, neo-functionalism, despite all its shortcomings, presents this advantage of reconciling both interest and identity basis of action in a comprehensive framework of explanation.

More recently in the 1990's, several approaches underlined the role of ideational factors in European integration. In the 'epistemic community' approach, ideas, beliefs, and attitudes, shared by a group of experts, constituted the explaining factors of international cooperation ${ }^{11}$. Without fully challenging the interest-based explanations, the epistemic community approach (re)introduced modestly the ideational dimension in the theoretical debate of European integration. In specific sectors where the technical expertise is relatively important such as in monetary policy, these international epistemic communities played a determinant role in policy-making process ${ }^{12)}$.

On monetary integration, McNamara's account of EMU process represented a synthetic approach combining the role of policy failures, neo-liberal consensus, and German emulation. European governments engaged in the EMU process because 1) former economic policies based on Keynesian recipe failed, 2) neo-liberal and monetarist monetary policy-stance became dominant among policymakers and central bankers everywhere in Europe, and 3) the economic and industrial success of German model emulated other governments ${ }^{13)}$. This explanation based upon the political economic functional need, the ideational and paradigmatic shift of policy-orientation, and finally the international policy-emulation constitutes a step forward a more satisfactory theoretical approach. Nevertheless, it fails to explain the Franco-British difference in European monetary integration. During the whole process of monetary integration, Britain had economic policy failures as much as other states, was a neo-liberal country par excellence, and was also exposed to the German emulation.

The constructivist approach in international relations addressed a fundamental

states": Ernest Haas, The Uniting of Europe: Political, Social, and Economic Forces, 1950-57, $2^{\text {nd }}$ edition, (Stanford: Stanford University Press, 1968), p.16.

11) Peter Haas, "Epistemic Communities and International Policy Co-ordination", International Organization, 46, 1, (1992).

12) A. Verdun, "The Role of the Delors Committee in the Creation of EMU: An Epistemic Community?", Journal of European Public Policy, 6, 2, (1999).

13) McNamara(1998). 
challenge to the interest-based approach. Methodological individualism, along with its materialistic and rationalistic premises, was criticized as a reductive research approach $^{14)}$. Constructivism insisted upon the concept of structuration where structure and agent are irreconcilably linked. In this approach, an agent's interest is not exogenously given but endogenously defined in the structural normative context $t^{15}$. In other words, identity defines interest and the materialistic premise of interest-based approach is rejected. Furthermore, agents are supposed to follow the logic of appropriateness based upon their identity and rules, rather than the logic of consequence deriving from rationalistic cost-benefit calculation ${ }^{16)}$.

Constructivist approach applied to European integration provided a variety of new insights ${ }^{17)}$. More specifically on monetary integration, a group of scholars have elaborated the concept of collective national identity as shared beliefs among nationals and proposed the resonance hypothesis ${ }^{18)}$. According to this hypothesis, the national preference formation on monetary policy is better explained by national political visions about the European political order, which in turn is a reflection of national collective identity. In short, state preference should resonate with collective identity. This plausible hypothesis is empirically verified by a study of elites' attitudes in three major member states (France, Britain, and Germany). France, on the one hand, projecting its own image of nation state into Europe, embraced the monetary unification. French elites were preoccupied by the question of "when" to embark on the single money adventure. On the other hand, in Britain, with her sense of particular national identity, the dominant question was "whether" to join the EMU or not.

Ideational and constructivist approaches contributed both to multiply conceptual tools, and improve the context sensitivity of explanation in dealing with national preference formation. However some weaknesses should be addressed, at least for the present stage of theoretical elaboration. First, ideas and identity covers such a wide range of substance that one can draw a variety of conclusions from the same idea or identity. Neoliberalism facilitated the French decision to join the EMU, but was powerless in the British context. The French Republicanism, grandeur, and the mission civilisatrice

14) Jeffrey Checkel, "The Constructivist Turn in International Relations Theory", World Politics 50, (January, 1998).

15) Alexander Wendt, Social Theory of International Politics, (Cambridge: Cambridge University Press, 1999).

16) James March and Johan P. Olsen, "The Institutional Dynamics of International Political Orders", International Organization, 50, 4, (1998).

17) K-E. Jorgensen, Reflective Approaches to European Governance, (Basingstoke: Macmillan, 1997).

18) Risse et al.(1999). 
promoted the European project, while the Imperial past and parlementarism in Britain constituted an obstacle to the EMU project ${ }^{19)}$. In other words, the complicated causal relations in terms of ideas and identity should be more rigorously established

Second, the risk of reification of national collective identities should be avoided. This risk, related to the first weakness of multiple interpretations and complex causal relations, forces researchers to be especially careful in their handling of ideas and identity. In order to avoid the reification of substantive ideas and identity, students of these approaches should keep in mind the instrumental use of ideational dispositions. In fact, collective identities can be exploited and transformed by political or ideological entrepreneurs for specific political purposes. It is then more appropriate, in certain circumstances, to include identity as one of the political resources that can be mobilized by political class and entrepreneurs rather than as an ensemble of fixed and invariable dispositions ${ }^{20)}$.

Third, one of the most challenging tasks for ideational approach becomes then the explanation of change in ideational dispositions. Without explaining why French national identity went through a transformative process of Europeanization in the 1980's while British national identity remained particularistic in the same period, the plausible resonance hypothesis looses its' persuasiveness. Here one clearly needs a theoretical account of ideational change which involves interest-based causal relations, as well as the instrumental dimension of ideas and identity.

\section{Bridging the gap}

The critical evaluation of both interest- and identity-based approaches points to the need for synthesis. Interest-based models focus on the choice of agents-either individuals or states-which depend on the 'objective' economic conditions they face. The 'subjective' perception and formulation of interests are neglected or ignored. On the contrary, identity-based models emphasize the subjective political visions without seriously taking account of economic interests. Even though one recognizes the need for concise and parsimonious model of explanation, these debates often ends with a 'dialogue de sourds'. As far as the EMU process is concerned, each approach claims superiority in its' explanatory power. Nevertheless neither denies the partial, residual, and complementary role of its' theoretical counterpart's explanation. Thus it seems tempting to elaborate a synthetic and combinatory approach in order to overcome these

19) Risse et al.(1999).

20) Jean-François Bayart, L’illusion identitaire, (Paris : Fayard, 1996). 
complementary models.

Furthermore, these approaches share at least two shortcomings. Political process is either absent or insignificant in both explanations. Concentrating on 'what' determines national preference, they neglect 'how' state interest is formulated. These theories tend to relate the causes (economic interests or national identity) directly to the policy orientation (commitment or refusal to EMU). The political process mediating these causes to policy is often poorly treated.

The other common feature is the posited universality of their model. Agents are supposed to behave always in the logic of consequence or that of appropriateness. Interest- or identity-based explanation is assumed to prevail in every context, issue, and actor. And two universal models of explanation can't coexist in scholarship. However empirical evidence supports partially both models of explanation and appeal for a theoretical reconstruction.

Finally, both approaches focused too much on the elites' analysis underestimating the latent or sometimes clear role of the masses in national preference formation. This selective attitude was perhaps understandable in the early years of European integration when the masses were merely aware of the huge process which was promised to transform their everyday life. This became less sustainable in recent decades with deepening integration, increasing interdependence, and reinforced visibility of European politics and policies ${ }^{21)}$. European integration has now a clear case for the (re)introduction of the masses in a new theoretical perspective.

\section{Hypotheses for the synthesis}

The synthetic approach proposed in this section is based upon two ideal types of agents' behavior and one central assumption. Interest-based model of explanation is catalyzed in a rationalist ideal type, while identity-based one is represented by a constructivist ideal type. Refusing the universal applicability of each model of explanation, the assumption posits a continuum relating these two ideal types of behavior. After defining these ideal types, the continuum assumption will be explained. Then we propose several ways to elaborate operational hypothesis and apply them to European integration.

Rationalist ideal type: Agents, motivated by their material self-interest, behave in

21) Vernon Bogdanor, "The European Union, the Political Class, and the People" in Jack Hayward (eds.), Elitism, Populism, and European Politics, (Oxford: Oxford University Press, 1996). 
such a way to optimize their well-being by cost-benefit calculation mobilizing their resources and information. The rationalist ideal type of behavior is best summarized in Homo Economicus model.

Constructivist ideal type: Agents, motivated by their subjective psychological dispositions, behave in such a way to optimize their social appropriateness by learning and following the situational constraints. The constructivist ideal type of behavior is to be found in Homo Sociologicus model, even if this latter model is more complex, various, and subject to discussion ${ }^{22}$.

Continuum assumption: In reality, rationalist and constructivist ideal types form two extreme poles of behavioral continuum and agents' behavior varies depending upon the role they play, the issue they deal with, and the stage where they act. We all know that agents switch from Homo Economicus to Homo Sociologicus, and that whatever the qualification agents are all Homo Sapiens! This central continuum assumption recognizes the ideal typical character of these models and makes them a dependent variable.

According to this perspective, an agent's behavior and his subsequent preference formation are different depending on the position on this continuum. One can think, decide and act following either a rationalist model of behavior or a constructivist one. The former is dominated by cost-benefit calculation, means-end mode of reasoning, and information gathering. The latter is based upon normative evaluation, commitmentresentment mode of reasoning, and socialization. In reality, human behavior is a mix of these two models and explanation of the variation along this continuum should constitute a necessary step in social scientific enquiry ${ }^{23)}$.

The main tasks of students of European integration then become 1) to identity the prevailing model of behavior at the agent (national, social, and individual) level, 2) to identify independent variables determining a particular position on the continuum, and 3) to investigate how the positions of different actors determine a specific attitude and combine in political process to produce a particular national preference.

At the agent level, three different characteristics at least can be identified. The

22) "Historically, roles that symbolically represent the total institutional order have been most commonly located in political and religious institutions": Peter Berger and Thomas Luckmann, The Social Construction of Reality: A Treatise in the Sociology of Knowledge, (New York: Anchor Books, 1967), p.76.

23) On the historical conceptual formation of 'interest' and its' association with rationalist mode of behavior, see Albert O. Hirschman, The Passions and the Interests: Political Arguments for Capitalism before Its Triumph, (Princeton: Princeton University Press, 1977), p.41: "One set of passions, hitherto known variously as greed, avarice, or love of lucre, could be usefully employed to oppose and bridle such other passions as ambition, lust for power, or sexual lust". 
rationalist agent's preference formation is emotionally and psychologically neutral while the constructivist one tends to be accompanied by more affective, psychological, and symbolic dimensions. The former insist more on the short term consequences and therefore tends to be variable, while the latter possesses a longer term consistence. Finally, rationalist agent's preference is issue-specific while constructivist counterpart's preference represents his more general attitude towards Europe.

Theoretically the agent's attitude for or against European integration can operate through rationalist or constructivist model. On the one hand, the pro- and antiEuropean attitude in the constructivist model can best be summarized in supranational federalism and 'sovereignist' nationalism. In this case, the attitude towards Europe is primarily determined by affective, psychological and symbolic attachment to the Nation State and the perception of it's relation with Europe. On the other hand, the same cleavage in the rationalist model can partially be exemplified by liberal-protectionist cleavage of affected interest groups. As already underlined, the rationalist model is more issue-specific, variable in time and space. On monetary issues to be discussed in detail later, the cleavage concerns the preference of exchange rate stability versus monetary policy flexibility.

Attitude and model of behavior

\begin{tabular}{|l|l|l|}
\hline \multicolumn{1}{|c|}{ Model } & \multicolumn{1}{|c|}{ Rationalist } & \multicolumn{1}{c|}{ Constructivist } \\
\hline \multirow{3}{*}{ Attitude } & Cost-benefit calculation & Emotional and symbolic \\
& Short-term and variable & Long-term and consistent \\
& Issue specific & General \\
& Elites & Masses \\
\hline \multirow{2}{*}{ Pro-European } & Liberalism & Federalism \\
& Stability & Europe as world power \\
\hline \multirow{2}{*}{ Anti-European } & Protectionism & Nationalism \\
& Flexibility & National pride \\
\hline
\end{tabular}

The above table is a condensed example of how the synthetic approach combining interest- and identity-based models can be analyzed with the attitude towards European integration. This simplified descriptive table renders what is to be explained more visible. It is now necessary to identity independent variables which can explain when, on what issue, and under what circumstances, an agent is more or less inclined to behave rationalistically or 'constructivistically'. Several hypotheses will be discussed in the following. 


\section{Core-Periphery}

Hypothesis 1: The longer the history of involvement in the European integration the stronger the inclination of an agent to behave on an identity-based ideal type.

This general hypothesis covers mainly agents at national level. Founding member states tend to have an identity-based reasoning, while more recent or would-be member states are inclined to have more interest-based cost-benefit reasoning. First, the formation of identity takes time ${ }^{24}$. It took at least several centuries for nation states to elaborate a national identity as one of the most preeminent identity-unit among citizens. Nevertheless, once the national identity is firmly established, agents tend more and more to behave on an identity model rather than an interest model. Scholars of nationalism often underline the central dimension of history in the national identity formation. Although the history of European integration is limited to half a century, European identity began to progressively emerge with such policies as the Common Agricultural and Commercial Policy, the European passport, the direct elections of European Parliament, the Single Market, and the Single Currency.

Second, the Europeanization process provokes and imposes an adjustment of national identity. The slow but inevitable emergence of a European consciousness along with integration process forces the existent national identity to Europeanize or reject Europeanization. It becomes increasingly difficult to discuss, to decide, to act only on the basis of interest calculation. Especially longer involvement in European integration imposes an adjustment to national identity, either to accept the new European identity in the national identity, or to remain outside and maintain an issue-centered relationship with Europe. Recent research indicates that the European and national identities are not automatically antagonistic and that they both tend to be opposed to the universal individualism which denies every kind of groupings except humanity composed of individuals ${ }^{25}$. Thus the adjustment of European and national identities is not always an antagonistic process but a more open process of complex interaction.

Third, a more complex core-periphery representation of Europe emerges progressively which reinforces or attenuates the initial mechanical hypotheses. For founding member states which also constitute the geographic core of the European Union it becomes a political imperative to maintain their core position. ${ }^{26)}$ For later member states, some have

24) Wendt(1999), pp.313-36.

25) Sophie Duchesne, Citoyenneté à la française, (Paris: Presses de Sciences Po, 1997).

26) For the importance of maps and geographic representation in the construction of imagined community', see Benedict Anderson, Imagined Communities, (London: Verso, 1983). 
been trying hard in order to access to the core, while others were content to stay at the periphery ${ }^{27)}$. The adjustment process of national identity to increased Europeanization should explain this complicated relation. Thus the time and space variables along with the resonance hypothesis of the constructivist school form the first group of determinants.

\section{Issue Specificity}

Hypothesis 2: The clearer the distributional consequences of policy integration, the stronger the inclination of an agent to behave on an interest-based ideal type.

The nature of issue determines here the nature of agents' behavior. This hypothesis takes account of the interest group model and the liberal intergovernmentalism of interest-based approach. Policies with clear distributional consequences such as the agricultural or commercial policies not only mobilize concerned interest groups but also impose a cost-benefit calculation-based reaction of other groups. On the contrary, issues with elusive distributional consequences tend to provoke identity-based reactions. Security or monetary affairs belong to this latter category.

However other dimensions of issue specificity should also be incorporated. Some social or policy-issues are more identity-sensitive depending on the historical context. In general, security and monetary issues have been highly identity-sensitive not only because of their elusive consequences but also because they constitute central elements of national identity. Human rights and democracy issues uphold a strong symbolic dimension in the recently democratized countries of Southern Europe. For Scandinavian countries, the uniqueness of their developed welfare state is accompanied by a strong symbolic and emotional attachment. Therefore, one corollary issue-specificity hypothesis should be added.

Hypothesis 3: Issues strongly associated with historical national formation tend to provoke identity-based behavior.

\section{Agent}

Hypothesis 4: Agents directly involved to policy integration tends to behave on an interest-based ideal type, while indirectly concerned agents tend to behave on an

27) The contrast is quite inspiring between 'poor' periphery states, eager to gain the status of developed industrial democracy by a zealous pro-European engagement, and 'rich' periphery states with more distant and reluctant rapport to Europe. 
identity-based ideal type.

The degree of agent's involvement is positively correlated with interest-based model of behavior. This hypothesis derived from the liberal political economic model is however corrected by its corollary stating a positive correlation between identity-based behavior and the lesser degree of involvement ${ }^{28}$. The masses can then be introduced in the analysis overcoming the limit of the original political economic model simply ignoring the populace.

This last hypothesis is correlated with the issue-specificity hypothesis but is not identical. An agent directly involved in a policy-issue with clear distributional consequences will tend to have a pure self-interested, calculated, and end-oriented behavior. A farmer with the Common Agricultural Policy (CAP), an exporter with the Common Commercial Policy (CCP) or the Single Market, represents this kind of situation. However, for a number of issues of elusive consequences, the masses or a voter will react on the identity-based model. And between these two clear cases, a variety of mix can be expected.

The synthetic approach combines the rationalistic and constructivist model of behavior on a continuum and attempts to identify the independent variables determining an agent's position on that continuum. This tentative elaboration is a preliminary effort to reintroduce the political process in the analytical framework, as well as the masses in the national preference formation, in order to overcome the limping universality claim of each approach. Now, we turn to the empirical application of this synthetic model in the French and British cases of European monetary integration.

\section{Commitment, Resentment, and Calculation}

In the long process of European monetary integration, the French attitude has been predominantly that of a commitment while the British has been mainly that of a calculation. When the discussion on monetary integration began at the end of the 1960's,

28) Berger and Luckmann emphasize the inevitable process of identity-based action as follows: "Since human beings are frequently sluggish and forgetful, there must also be procedures by which these meanings can be reimpressed and rememorized, if necessary by coercive and generally unpleasant means. Furthermore, since human beings are frequently stupid, institutional meanings tend to be simplified in the process of transmission, so that the given collection of institutional "formulae" can be readily learned and memorized by successive generations. The "formula" character of institutional meanings ensures their memorability". Berger and Luckmann(1967), p.70. 
France was a core member state in EC while Britain was not yet a member country. At the moment of completion of monetary integration in January 2002, France has achieved her transition into the single currency along with ten other member states while Britain was still calculating the propitious time of the decisive referendum on her participation. After the successful launch of the euro zone, France has become more than ever a core country in Europe, while Britain is still hesitating on this monetary engagement. In this section, we analyze comparatively France and Britain since the early 1970's in order to empirically verify the hypotheses proposed in the previous section.

\section{Between Head and Heart}

According to the core-periphery hypothesis, France, which is one of the founding states of both the European Coal and Steel Community (1951) and the European Economic Community (1958), is expected to have a more identity-based pattern of relationship with Europe. Even at the beginning of the European integration process in the 1950's, we can observe that some social and political movements in France are particularly important in igniting the pan-European mobilization and in supporting these very early projects. On the contrary, Britain, which joined the Community only in 1973 , is expected to have a more prudent and calculated rationalist approach to Europe. The legacy of late accession ${ }^{29)}$ as well as the market-oriented socio-economic model, vulnerable unwritten constitution, parliamentary definition of sovereignty, adversarial political culture and highly centralized power structures, have been identified as main factors explaining the British distant relationship with Europe ${ }^{30}$.

However the first experience of European monetary cooperation in the 1970's, namely the monetary Snake, doesn't seem to provide a strong confirmation of core-periphery hypothesis. France is as inconstant as Britain in her commitment to the cooperation framework. In less than two years since the launch of the Snake, she withdrew her participation in January 1973. She rejoined briefly the Snake in December 1975 to exit again the next year. France doesn't seem to be motivated by identity-based feelings, but short-term economic interests ${ }^{31}$. The British case is already characteristic of her later

29) Wallace, Helen, "At Odds with Europe", Political Studies, XLV, (1997), pp.678-88.

30) Dyson and Featherstone insist also on the preeminence of 'economic interests' over 'emotional commitment' in the British case: "Policy had been led by 'Europeans' of the head rather than of the heart": Kenneth Dyson and Kevin Featherstone, The Road to Maastricht: Negotiating Economic and Monetary Union, (Oxford: Oxford University Press, 1999), p.534.

31) Moravcsik(1998). 
pattern: British participation ended only six weeks after in June 1972 for never rejoining any European monetary arrangement until 1990. But above all, France sought to elaborate a more successful institutional setting of monetary cooperation to deal with the failure of the monetary Snake. This search for a European solution can thus be characterized as a reflection of the French core-ness as opposed to the British peripheral status in Europe.

The Franco-German initiative of the EMS, which began in 1979, represents another example of Franco-British contrast. As expected by the hypothesis, France was the founding leader of this cooperative framework while Britain remained outside during all the 1980's. Even though France was as inconsistent as Britain for the monetary Snake experience, she put forward her European commitment by this new institutional design. This contrast is all the more reinforced that France experienced one of the most painful economic crisis in the beginning of the EMS and chose to stick to the rules of the cooperative game. Britain facing comparable economic crisis was also embarked on a deflationary monetarist experiment under Margaret Thatcher but remained outside the EMS. This initial choice has been maintained even when economic conditions dictated British participation between 1985 and 1990 reflecting the personal resentment of the Prime Minister Thatcher toward Europe. The divergent policies of the 1980's are symptomatic of the French pro-European commitment and the British anti-European resentment and form the bases of a critical juncture.

In the 1990's, the choice of both countries in the Maastricht Treaty revealed this different attitude. France embarked on the Economic and Monetary Union (EMU) process, while Britain sought and was successfully offered an opt-out to monetary unification. Theoretically, Britain had the possibility to join the EMU just like other EU countries. But the Exchange Rate Mechanism (ERM) crisis of 1992-3 reconfirmed the French commitment and the British resentment. France clearly chose to stick to the plan whatever painful would be the cost of adjustment. Britain, faced to the short term economic losses, chose to exclude herself from the cooperative framework. Especially after the crisis, France pursued deflationary economic policy efforts in order to meet the Maastricht criteria while Britain remained outside until the achievement of the monetary union in 1999. Nevertheless British new Labour government has proclaimed the principle of British participation in the single currency project with its' own conditions. These are named the five economic tests according to the five criteria proposed by the British government in 1997: sustainable convergence between Britain and the economies of the euro zone, sufficient flexibility to cope with economic change, the effect on investment, the impact on British financial services industry, the effect on 
employment ${ }^{32)}$. So far the British government considers the country has not met these economic tests. But the real reason for British hesitation must be found in the political dimension of the economic engagement and not in the so-called economic tests.

\section{Common Elusiveness}

The issue-specificity hypothesis operates mainly at the European level. Issues with clear distributional consequences tend to mobilize interest-based attitude and action at both individual and national level. At the same time, issues with elusive distributional consequences should provoke more identity-based reactions. This hypothesis reveals to be useful when comparing different patterns of integration in different issue-areas rather than in a cross-country analysis. As underlined above, the monetary issue has more elusive distributional consequences than the commercial issue. At the same time, the distributional consequences of monetary integration seem to be clearer than that of security cooperation. For these cross-country comparative purposes, monetary integration has globally the same impact on both countries.

Considered in more detail, however, political economic analysis indicates monetary integration has different distributional impact on Britain and France depending on their respective economic structure and situation. The French trade structure is more dependent on European partners while the British one is more globally oriented. More important was the convergence of business cycle with other European member states. But basically the elusiveness of the monetary integration and its' distributional consequences applies to both Britain and France. Furthermore, subjective perception of economic interests may be more important than the simple distributional consequences. It has been argued British business preferred the monetary autonomy and flexibility rather than stability, with big business and financial sector more favorable to the EMS and the EMU than small and medium size business. Quite surprisingly the Trade Union Congress (TUC) supported the EMU in the 1990's and this is hardly explainable in this framework. In the campaign for British general election of 1997, big business and financial sector were exhausted by the British conservatives' division and incapacity to promote a clear European policy so much so that even the Financial Times proclaimed their support for the Labour. As we can see in this case, the political representatives don't automatically reflect the interests of their principal constituency, especially if the

32) Britain's economy: the euro,

http://www.britainusa.com/sections/index_nt1.asp?i=41137\&L1=41012\&L2=41012（검색 일:2005.11.21) 
issue doesn't have clear-cut distributional consequences.

We can conclude by indicating that the issue specificity hypothesis has a neutral effect on both France and Britain. Even though some differences can be observed in terms of economic and monetary structure of those two countries, these differences can't by themselves clearly explain each country's preference. One should turn to a more historical and qualitative analysis with our corollary hypothesis.

\section{Pride and Instrument}

How deeply is the monetary issue involved with the national formation of France and Britain? Three different historical experiences at least separate these two countries as far as the national currency is concerned. In each experience, France, compared to Britain, has developed a more flexible rapport between national currency and national identity so much so that the concept of monetary sovereignty provokes much more identity-based reactions in the latter country.

First, France has already experienced international monetary arrangement involving economic powers of comparable size, allowing international cooperation. In 1865 France formed the Latin monetary union with Italy, Belgium, and Switzerland and this union lasted until World War I before being formally dissolved in $1927^{33)}$. This cooperation framework reflected both a relative vulnerability of France in the Gold standard international monetary order and the central position of Britain. In this perspective, the gold standard monetary order has been an early cleavage of French/British contrast in monetary affairs since at least the end of the 19th century and seems to have contributed to the identity of both countries. This cooperative experience should be distinguished from monetary bloc formation in which Britain or France functioned as core hegemonic power. In the 1930's the Sterling zone as well as the Franc zone permitted each country to have a monetary stability zone in its empire. While the hegemonic experience tends to reinforce the monetary sovereignty feelings, only international cooperative experience develops the sense of relativity of monetary matters.

Second, the monetary policy pattern of these countries differed considerably during most of the 20th century. In the aftermath of the 1st World War, Britain chose to maintain the pre-War parity of Sterling with gold putting her currency value at an

33) Benjamin Cohen, "Beyond EMU: The Problem of Sustainability" in Barry Eichengreen and Jeffrey Frieden(eds.), The Political Economy of European Monetary Unification, (Boulder: Westview Press, 1994). 
economically unsustainable level. Since then, "macroeconomic policy in Britain, from 1918 to the floating of the pound in 1972, was dominated by a concern to maintain the value of sterling on the foreign exchanges" ${ }^{34)}$. France, more realistically, devalued her currency value and fixed the Franc Poincare at one fifth of its pre-War level. Even though Britain had also to devalue her currency value in the crisis years of 1930's, the same difference reappeared in the post-second World War years. This different policy pattern reflects differences in their respective economic structure as well as in interest intermediation. Nevertheless, the repeated policy choices of each nation influenced the general perception of national currency. On the British side, the pound Sterling became a symbol of national sovereignty, of glorious and prosperous imperial past. On the French side, the national currency became to be perceived as an instrument of economic growth and development, especially with the post War experiences of repeated devaluations and monetary reform ${ }^{35)}$.

Third, the overwhelming political power of financial capital in Britain fostered the concept of the pound sterling as the symbol of national sovereignty. In France, the state control of financial capital reinforced the instrumental character of the monetary policy ${ }^{36)}$. These three arguments point to the British pride in Sterling and French instrumental vision of Franc. From this perspective, the British has tendency to react on the basis of identity on monetary matters while the French will be more flexible and have a more interest-based reaction.

\section{Indifferent masses?}

The fourth hypothesis introduces the masses in the process of national preference formation. Compared to the interest groups or the policymakers directly involved in the national preference formation, the masses constitute a concerned public with intermittent intervention. According to our hypothesis, these masses tend to have an identity-based attitude and behavior while interest groups and policymakers have a more interest-based mode of reasoning. However it is extremely difficult to find evidence on the exact way the masses reason and behave ${ }^{37)}$. Thus our empirical

34) Peter Hall, "The State and Economic Decline" in Bernard Elbaum and William Lazonick (eds.), The Decline of the British Economy, (Oxford: Clarendon Press, 1986), p.269.

35) Elie Cohen, La tentation hexagonale: La souveraineté à l'épreuve de la mondialisation, (Paris: Fayard, 1996).

36) John Zysman, Governments, Markets, and Growth: Financial Systems and the Politics of Industrial Change, (Ithaca: Cornell University Press, 1983).

37) The persistent divergence between opinion polls and real voting behavior in elections and referenda on Europe reflects this difficulty to analyze masses' attitude : Bogdanor(1996). 
application will be limited to the examination of opinion surveys and the discussion of some qualitative arguments.

Since the 1970's when the European monetary cooperation began, numerous opinion surveys have confirmed the French masses enthusiasm for and the British masses reluctance against the monetary integration. Some variations appear in time but the French support and the British opposition, or more indifference, are quite regularly reconfirmed. Unfortunately, these surveys are not systematically supplemented by the motivation study of the masses. It is therefore useful to appeal to indirect evidences.

The first indirect evidence is provided by the concordance of the masses attitude with the conclusions of the historical national formation. In the previous hypothesis examination, France was supposed to have a more flexible and interest-based approach to European monetary integration. Britain was characterized by more rigid attachment to monetary sovereignty and identity-based approach. For the masses, the impact of the national monetary policy pattern is negative in Britain and indifferent in France. Second, the core-periphery hypothesis underlined the identity-based core-ness in the French case and the interest-based peripheral character in the British case. In this case, the impact must be positive for the French masses and indifferent for the British ones.

Recent opinion polls seem to support our conclusions. First the French are more interested in both the general aims of the European Union and on the European Currency than the British. In France 83\% and 79\% indicate their interest to the aims and objectives of the European Union, and to the European Currency, respectively. These figures are $65 \%$ and $65 \%$ in the British case ${ }^{38}$. Second, France is one of the most supportive nations of the single currency (63\% for, 30\% against) while Britain is the most reluctant country (27\% for, 58\% against) in autumn 2001. Third, an opinion survey of top decision makers indicates similar difference between France and Britain ${ }^{39}$. The support of the single currency is $89 \%$ for French elites and only $60 \%$ for the British ones. Among the supporters, the French indicate primarily economic and political reasons (53\% and 50\% respectively), while the British tend to put forward economic and commercial reasons (28\% and $34 \%$ respectively). Finally a qualitative opinion study based upon group discussion contrasts the French and the British attitudes. For the

38) Europinion \#13, November 1997, http://europa.eu.int/comm/dg10/epo/eo/eo13/13-txt_en.html (검색일: 2005.10.20).

39) This leadership opinion survey covers the elected politicians, high level civil servants, business and labor leaders, the media, and academic, cultural, and religious leaders: The European Union, "A View from the Top", 1996, http://europa.eu.int/comm/dg10/epo/eb-top/en/top.pdf (검색일: 2005.10.20). 
former, the EU is a political and economic entity whose clear purpose is to 'counter' the US and Japan on international scene. For the latter, Europe still remains something external and the proximity with the US is more generally shared ${ }^{40)}$.

Even if the issue of European Constitution does not directly concern monetary unification, the failure of ratification of the French referendum on May 29, 2005 should be considered ${ }^{41)}$. One can take this failure as a significant change in the French public opinion from pro to anti-European attitude. This is partly true, but we should also take account the fact that a big number of opponents to the ratification were pro-European and that they favored a more socially-oriented European integration instead of the present neo-liberal stance. These left-wing partisans of 'non' pointed their fingers to the European Central Bank and its' monetary policy nearly exclusively oriented to the anti-inflationary objective. Supported by labor classes, urban low status employees and unemployed, they asked for a more growth-oriented monetary policy. They weren't for French national monetary policy but for a European scale Keynesian distributive and redistributive economic policy, and in this sense, they have again confirmed the French core-ness in Europe.

The political elites' strategy reflects both their own path dependent trend and the general public's attitude. In France, where the European core-ness is generally shared by both the elites and the masses, the political elites could develop a cooperative and integrationist strategy helped by the support of business elites' search for monetary stability. In Britain with an arms-length interest-based attitude towards Europe both at the masses and the business elites' level, the political elites had to deal with the firmly anti-European identity of sovereignists. The symbolic dimension for integration is either absent or negative for large sections of British opinion ${ }^{42}$. Tories' disintegration can then be explained as a political battle between Europeans by head and antiEuropeans by heart ${ }^{43)}$. In the parliamentary conservative party (1992-7), Eurosceptics (55\%) surpasses Europhiles (25\%) while Undecided represent 20\%. After the 1997 general election, the proportion of Eurosceptics is reinforced to 59\% while Europhiles and Undecided represent respectively $23 \%$ and $17 \%$. And in the 1990's, the most important cleavage between Europhiles and Eurosceptics in the conservative party has been on the issue of monetary union. On the other hand, Blair's Labour party pro-European stance

40) Perceptions de l' Union Européenne : Attitudes et attentes à son égard, June 2001, http://europa.eu.int/comm/dg10/epo/gov/eu2001_fr.pdf (검색일: 2005.10.15).

41) http://francepolitique.free.fr/referendum2005.htm (검색일:2005.12.21).

42) Helen Wallace, "At Odds with Europe", Political Studies, XLV, (1997), p.686.

43) John Turner, The Tories and Europe, (Manchester: Manchester University Press, 2000). 
must be considered as a consequence of general transformation of the British left from an ideological movement to a more subtle instrument of power conquest.

\section{Conclusion}

The aim of this paper was to explain the different French and British attitudes toward European monetary integration. The starting point is the critical evaluation of existent approaches in providing a satisfactory explanation of Franco-British differences. Both interest- and identity-based approaches provide a partially relevant explanation but fail to capture other important dimensions. Our attempt is then to formulate an articulated synthesis combining these two approaches and to propose some operational hypothesis. Positing two opposite models of action, one rationalist and the other constructivist, and assuming a continuum between these two extremes, we elaborate the basic analytic framework. Then, we propose four operational hypotheses on European integration concerning the core-periphery dimension, the distributional consequences of the issue, the rapport of the issue to the national formation and identity, and the agent involvement dimension. Analyzed in the light of these four dimensions, the explanation becomes more complete and satisfactory. In France, the globally pro-European identity shared by the masses combined with the economic elites support or neutrality was opportunistically and successfully exploited by political elites. On the contrary, in Britain, the political and economic elites were both hesitant on the monetary integration, as well as on the European integration in general, constantly measuring the pros and cons of participation. The masses attitude against monetary integration reflects the particular status of the national currency in their historical imaginary and the peripheral nature of British European commitment. Our synthetic framework seems to produce a more comprehensive account and explanation than each approach considered in isolation without immerging in descriptive details. The next step would be to verify the usefulness of this framework for extended empirical cases.

First, the empirical test concerning France and Britain in European monetary integration should be further applied to other countries. Actually, all the core countries decided to participate to the EMU, while periphery countries developed a divergent pattern of attitude. States of the southern periphery all joined the EMU. On the northern periphery, Britain, Denmark, and Sweden, remain outside while Ireland and Finland are among the first group of the single currency. It would then be particularly interesting to compare the periphery countries among themselves, extending our 
comparison of core-periphery countries. Second, other issues of integration can provide the test for the usefulness of this framework and for the validity of the hypothesis. The commercial policy integration on the one hand, and the security and foreign policy integration on the other, can be usefully analyzed and compared with the monetary integration case. Third, the framework can also be applied to other cases of national preference formation. The hypothesis examined in this paper can carefully be adapted and applied for extended international cooperation cases and issues.

Interests and Identity in Monetary Unification

\begin{tabular}{|l|l|l|}
\hline & \multicolumn{1}{|c|}{ France } & \multicolumn{1}{c|}{ Britain } \\
\hline \multirow{2}{*}{ Core-periphery } & $\begin{array}{l}\text { Identity based } \\
\text { Coreness }\end{array}$ & $\begin{array}{l}\text { Interests based } \\
\text { Periphery }\end{array}$ \\
\hline \multirow{2}{*}{ Issue specificity } & $\begin{array}{l}\text { Neutral } \\
\text { Elusiveness }\end{array}$ & $\begin{array}{l}\text { Neutral } \\
\text { Elusiveness }\end{array}$ \\
\hline \multirow{2}{*}{ National identity formation } & $\begin{array}{l}\text { Interest based } \\
\text { Instrumental }\end{array}$ & $\begin{array}{l}\text { Identity based } \\
\text { National pride }\end{array}$ \\
\hline \multirow{2}{*}{ Masses } & Identity based & $\begin{array}{l}\text { Identity based } \\
\text { Periphery + National Pride }\end{array}$ \\
\hline
\end{tabular}




\section{REFERENCES}

Anderson, Benedict, Imagined Communities, (London: Verso), 1983.

Artis, Michael J., The UK and the EMU, EU Working Papers RSC No.67, (Florence: European University Institute), 2000.

Balls, Ed, "Why the five economic tests?", World Economics, Vol.4 No.1, (2003).

Bayart, Jean-François, L'illusion identitaire, (Paris: Fayard), 1996.

Berger, Peter L., and Thomas Luckmann, The Social Construction of Reality: A Treatise in the Sociology of Knowledge, (New York: Anchor Books), 1967.

Bilefsky, Dan, and Ben Hall with Lionel Barber(eds.), The Birth of the Euro: the Financial Times's Guide to Emu, (London: Penguin Books), 1998.

Bogdanor, Vernon, "The European Union, the Political Class, and the People" in Jack Hayward(eds.), Elitism, Populism, and European Politics, (Oxford: Oxford University Press), 1996.

Checkel, Jeffrey T., "The Constructivist Turn in International Relations Theory", World Politics 50, (January, 1998).

Cohen, Benjamin J., "Beyond EMU: The Problem of Sustainability" in Barry Eichengreen and Jeffrey Frieden(eds.), The Political Economy of European Monetary Unification, (Boulder: Westview Press), 1994.

Cohen, Elie, La tentation hexagonale: La souveraineté à l'épreuve de la mondialisation, (Paris: Fayard), 1996.

Dyson, Kenneth, and Kevin Featherstone, The Road to Maastricht: Negotiating Econonomic and Monetary Union, (Oxford: Oxford University Press), 1999.

Eichengreen, Barry, "Dental Hygene and Nuclear War: How International Relations Looks from Economics”, International Organization 52, 4, (1998).

Eichengreen, Barry, and Jeffrey Frieden(eds.), The Political Economy of European Monetary Unification, (Boulder: Westview Press), 1994.

Frieden, Jeffrey A., "The euro: Who wins? Who loses?, Foreign Policy, September (1998).

Frieden, Jeffrey A., "The Impact of Goods and Capital Market Integration on European Monetary Politics”, Comparative Political Studies 29, (1996).

Frieden, Jeffrey A., "Invested interests: The politics of national economic policies in a world of global finance", International Organization 45, No.4, Autumn (1991)

Gamble, Andrew, The Free Economy and the Strong State: The Politics of Thatcherism, 2nd edition, (London: MacMillan), 1994. 
Goodman, John B., Monetary Sovereignty: The Politics of Central Banking in Western Europe, (Ithaca: Cornell University Press), 1992.

Haas, Ernest B., The Uniting of Europe: Political, Social, and Economic Forces, 19501957, 2nd edition, (Stanford: Stanford University Press), 1968.

Haas, Peter M., "Epistemic Communities and International Policy Co-ordination", International Organization, 46, 1, (1992).

Hall, Peter, "The State and Economic Decline" in Bernard Elbaum and William Lazonick (eds.), The Decline of the British Economy, (Oxford: Clarendon Press), 1986.

Henning, C. Randall, "Systemic Conflict and Regional Monetary Integration: The Case of Europe", International Organization, 52, 3, (1998).

Hirschman, Albert O., The Passions and the Interests: Political Arguments for Capitalism before Its Triumph, (Princeton: Princeton University Press), 1977.

Jorgensen, K.-E., Reflective Approaches to European Governance, (Basingstoke: Macmillan), 1997.

March, James G., and Johan P. Olsen, "The Institutional Dynamics of International Political Orders", International Organization, 50, 4, (1998).

Marcussen, M., T. Risse, D.Engelmann-Martin, H-J. Knopf, and K.Roscher, "Constructing Europe? The Evolution of French, British and German Nation State Identities”, Journal of European Public Policy, Vol.6, No.4, (1999).

McKinnon, Ronald, "Optimum Currency Areas”, American Economic Review, 53, (1963).

McNamara, Kathleen, The Currency of Ideas: Monetary Politics in the European Union, (Ithaca: Cornell University Press), 1998.

Merlingen, Michael, “Identity, Politics and Germany's Post-TEU Policy on EMU”, Journal of Common Market Studies, Vol.39, No.3, (September, 2001).

Moravcsik, Andrew, The Choice for Europe: Social Purpose and State Power from Messina to Maastricht, (Ithaca: Cornell University Press), 1998.

Moravcsik, Andrew, "Taking Preferences Seriously: A Liberal Theory of International Politics", International Organization, Vol.52, No.4, (1997).

Moravcsik, Andrew, "Preferences and Power in the European Community: A Liberal Intergovernmentalist Approach", Journal of Common Market Studies, Vol.31, No.4, (1993)

Mundell, Robert, "A Theory of Optimum Currency Areas", American Economic Review, 51, (1961).

Parsons, Craig, "Showing Ideas as Causes: The Origins of the European Union", International Organization, Vol.56 No.2, (2002). 
Pierson, Paul, "The Path to European Integration: A Historical Institutionalist Analysis", Comparative Political Studies, Vol.29 No.2, (1996).

Risse, Thomas with Daniela Engelmann-Martin, Hans-Joachim Knopf and Klaus Roscher, "To Euro or Not to Euro? The EMU and Identity Politics in the European Union”, European Journal of International Relations, Vol.5, No.2, (1998).

Schmidt, Vivien A., From State to Market: The Transformation of French Business and Government, (Oxford: Oxford University Press), 1996.

Théret, Bruno, 'Néo-libéralisme, inégalités sociales et politiques fiscales de droite et de gauche dans la France des années 1980: Identité et différence, pratiques et doctrines', Revue Française de Science Politique, Vol.41, No.7, (1991).

Turner, John, The Tories and Europe, (Manchester: Manchester University Press), 2000.

Verdun, A., "The Role of the Delors Committee in the Creation of EMU: An Epistemic Community?", Journal of European Public Policy, 6, 2, (1999).

Wallace, Helen, "At Odds with Europe”, Political Studies, XLV, (1997).

Wendt, Alexander, Social Theory of International Politics, (Cambridge: Cambridge University Press), 1999.

Zysman, John, Governments, Markets, and Growth: Financial Systems and the Politics of Industrial Change, (Ithaca: Cornell University Press), 1983.

Eurobarometer 56, Autumn 2001, http://europa.eu.int/comm/dg10/epo/eb/eb56/eb56_enfinal.pdf (검색일: 2005.10.15)

Europinion \#13, November 1997 , http://europa.eu.int/comm/dg10/epo/eo/eo13/13-txt_en.html (검색일: 2005.10.20)

Perceptions de l' Union Européenne : Attitudes et attentes à son égard, June 2001, http://europa.eu.int/comm/dg10/epo/gov/eu2001_fr.pdf (검색일: 2005.10.15)

The European Union: "A View from the Top”, 1996, http://europa.eu.int/comm/dg10/epo/eb-top/en/top.pdf (검색일: 2005.10.20)

Référendum du 29 mai 2005 sur la constitution européenne, http://francepolitique.free.fr/referendum2005.htm (검색일:2005.12.21)

Britain's economy: the euro, http://www.britainusa.com/sections/index_nt1.asp?i=41137\&L1=41012\&L2=41012 (검색일:2005.12.21) 